\title{
CRIMINALS AMONG THE WOMEN IN THE FERGHANA VALLEY AND ITS NEGATIVE EFFECTS
}

\author{
Marguba Makhsudovna Nosirova \\ Senior Lecturer, Department of "Theory of Civil Society" of Andizhan State University, \\ Republic of Uzbekistan
}

Article DOI: https://doi.org/10.36713/epra3989

\begin{abstract}
In this article is discussed process of criminals among the women in the Ferghana valley and its negative effects by the media sources and materials of juridical documents as well.
\end{abstract}

KEY WORDS: Ferghana valley, women, nationality, upbringing, morality, ethics, Gender, result, offence.

\section{INTRODUCTION}

Nowadays, in the world, the attention to women is changing radically. After all, the value, respect and admiration of women that ensure the continuity of each nation and ethnicity is the basis for the continuity of generations. In the ancient East, education and education are seen as a factor in which human morality and spirituality are inseparable. Therefore, when Eastern thinkers say, "The knowledge that is not brought up is the sword in the hands of the immoral," it is easy to understand how education and education are an integral link. Looking back over three thousand years of the history of the Uzbek people, we can see that its spiritual and moral upbringing plays an important role in the life of our ancestors, in the human development. Understanding the importance of spiritual and moral education in human development, our mothers and grandmothers have assumed the responsibility of raising children more than men. Consequently, the mother gives birth not only to the followers of the nation and nation, but also to the intellectual, physical, moral, and spiritual development of the child, whitening the child to white and doing good deeds [1].

\section{METHODS}

In fact, at first glance, the issue of gender equality for our women, who have taken up the difficult task of raising children, is of global importance, and is reflected in the UN documents, including the 2015 Resolution 70 . In order to organize systematic work on the accelerated implementation of the UN Sustainable Development Goals, the country sets out the national goals and objectives for sustainable development in Uzbekistan until 2030. According to her, the $5^{\text {th }}$ goal of Uzbekistan's sustainable development until 2030 is to promote gender equality and empower all women. This includes economic, social, legal and other measures. All state bodies and organizations, institutions, as well as public organizations of state significance are responsible for the fulfillment of these tasks. A coordinating Council on the implementation of national goals and objectives in the field of sustainable development until 2030 has been established. As a result of the reforms being implemented in this area, there have been some changes in our national legislation as well. In particular, the law "On guarantees of equal rights and opportunities for women and men" was adopted on September 2, 2011.

\section{RESULTS AND DICSUSSIONS}

Adopted by the Senate on August 17, 2019, approved by the Senate on August 23, 2019, President of the Republic of Uzbekistan Sh. Mirziyoev Article 3 of the Law of the Republic of Uzbekistan "On Guarantees of Equal Rights and Opportunities for Women and Men", approved by Mirziyoev on September 2, 2019, N-562, applies the following basic terms:

- Provisional special measures to ensure the implementation of gender policy - legal, organizational and institutional measures undertaken 
by the state authorities to address specific goals of eliminating gender inequality, ensuring true or justified gender equality;

- Gender - the social aspect of the relationship between women and men in all spheres of public life and activity, including in the areas of politics, economics, law, ideology and culture, education and science;

- Gender Statistics - Gender statistics and relationships in all spheres of social and political life reflect the relevant status of persons of different sexes in all spheres of social and political life, including information on the state of women and men in all areas of public life and activity. illuminating part;

- Gender and legal expertise - analysis of regulatory legal acts and their projects for compliance with the principles of ensuring equal rights and opportunities for women and men;

- gender discrimination - any discrimination, exclusion or restriction, including discrimination on the basis of marital status, pregnancy, family obligations, as well as sexual abuse in all areas of public life and activities aimed at non-recognition of the rights and freedoms of women and men; pay different kinds of work, equal work and qualifications;

- Indirect discrimination by gender - creating situations, situations or criteria that make same-sex persons more disadvantaged than other sexes, including the promotion of gender inequality through the media, education, culture, and negative consequences for a particular gender - establishing conditions or requirements [2].

Today, despite numerous reforms to prevent gender discrimination in the promotion of gender equality between men and women, there is some gender discrimination in society. For example, in some families males and females have a misunderstanding of each other, or as a result of the abuse of alcoholic men by the caregivers of the same family, family disputes result in the loss of a healthy atmosphere in conflict families. And the loss of a healthy environment in the family is more likely to have a negative impact on the upbringing of the younger generation than on its positive effects. Particularly, the negative effects of such negative influences in adolescents, such as insecurity, indifference and indifference, have a significant impact on the development of state and society. That is why a new system has been created to improve the spiritual atmosphere in families and to facilitate the work of public organizations.

In particular, at the expanded joint session of the Council of Chambers of the Oliy Majlis on "Prevention of Offenses and the Fight Against
Crime", there was a critical review of the increase in female crime in the Andijan region, particularly in the Fergana valley. Despite some efforts to prevent crime and crime committed by women in the region, ensure the stability of the social and spiritual atmosphere in families, as well as identify and address problems, there is a growing incidence of women crime and crime. In particular, in the first seven months of this year, women committed 286 crimes. In addition, early births and family rewards increased over the same period last year, with 52 women committing suicide. Most of the crimes mentioned were fraud, forgery of documents, illegal entry abroad, embezzlement or embezzlement of state property, theft of other people's property, and intentional bodily injury. In Jalakuduk district, one murders require the prevention of and possible crime in the region. In this regard, 83 families of crime-prone and 102 women returned from the penitentiary institutions, 315 families of offenders, as well as 462 disadvantaged families are working individually. In turn, these women were taken under special control and provided social assistance to involve 50 women who had previously been convicted and returned from penitentiary institutions for socially useful work and to provide psychosocial support. In particular, 11 of these women have been employed on a regular basis, 13 of them have been assisted by regional authorities and civil society institutions in providing their own health, and 15 have received financial assistance, 12 have received legal advice, and 9 have received psychological counseling.

Together with women's committees and partner organizations operating in the Andijan region, 120,807 homes were included in the total number of 21,230 problems identified in these apartments. Of the revealed problems 13,959 were solved in the same place, 2,998 were solved at the district level and 49 at the regional level [3].

In Andizhan region, a number of effective measures have been taken to prevent female crime, including the social and legal protection of the "Charity to you" women and their families working in the region to provide social, legal and psychological support to women deported from foreign countries. The center's activities are further improved. Currently, such centers are opened in Andizhan, Asaka, Balikchi, Izboskan, Altinkul, Shahrikhon, Kurgantepa districts.

In the Fergana region, which is the only pearl of the Ferghana Valley, there has been an increase in female crime, with 608 crimes committed by 668 women over the past 10 months of 2019. Most of the crimes were committed in Baghdad, Dangara, Buvaida and Yozyovon districts. This has led to a 
dramatic increase in the number of female crimes in these areas [4].

Increasing crime in women in Fergana region, along with theft and robbery, as well as the increasing number of sexual harassments outlawed in modern laws that are not quite compatible with our nationality, should not be neglected by the general public. However, a woman from the Besharik district of Fergana region, a woman suspected of forcing her underage girl (14) to have sex with a man for her own humanistic purpose, mediated three men for having sex with their daughter. A forensic examination revealed that the girl's 17 - to 18 -week-old fetus was aborted artificially. Senate Speaker Tanzila Norboeva, commenting on the crimes of women who have committed this abnormal form of humanity by exploiting their underage children for abusive purposes, called on the public to address the relevant authorities when they became aware of such cases. In turn, Tanzila Norboeva acknowledged that there was no effective communication between preventive inspectors, civil self-government bodies, schools and the Youth Union to prevent such cases [5].

\section{CONCLUSION}

In conclusion, it is necessary to pay special attention to ensuring the welfare of the society and the people in the country, and above all, to the welfare of the population. In spite of numerous practical reforms in this regard, increased crime among women has had a negative impact on the development of our society and our state.

In particular, in the Ferghana Valley, which is the most populous country in Uzbekistan, there are several factors contributing to increased crime among women:

- the high unemployment rate among working women, which has led to the worsening of their social status;

- The deterioration of social conditions in families contributes to the increasing crime of theft among women:

- One of the crimes among women is the increasing number of motivated women to engage in illegal sexual intercourse with other people for the sake of making a living.

\section{REFERENCES}

1. Look: S. Joldasova // http://uza.uz/oz/society/gender-tengliktaminlanadi-17-09-2019

2. National database of legislation, 03.09.2019, № 03/19/562/3681//http://lex.uz/docs/4494849

3. Why women crime and family prevalence in Andijan have increased?

4. https://aniq.uz/yangiliklar/andijonda-xotin-qizlarjinoyatchiligi-va-oilaviy-ajrimlar-nega-kupaygan

5. In Ferghana 668 women committed crimes //https://aniq.uz/yangiliklar/fargonada-668-nafarxotin-qiz-jinoyatga-qul-urdi

6. TanzilaNorboeva //https://zamin.uz/jamiyat/40824-fargonada-onauz-qizini-jinsiy-aloqaga-majburlaganlikdagumon-qilinmoqda.html 